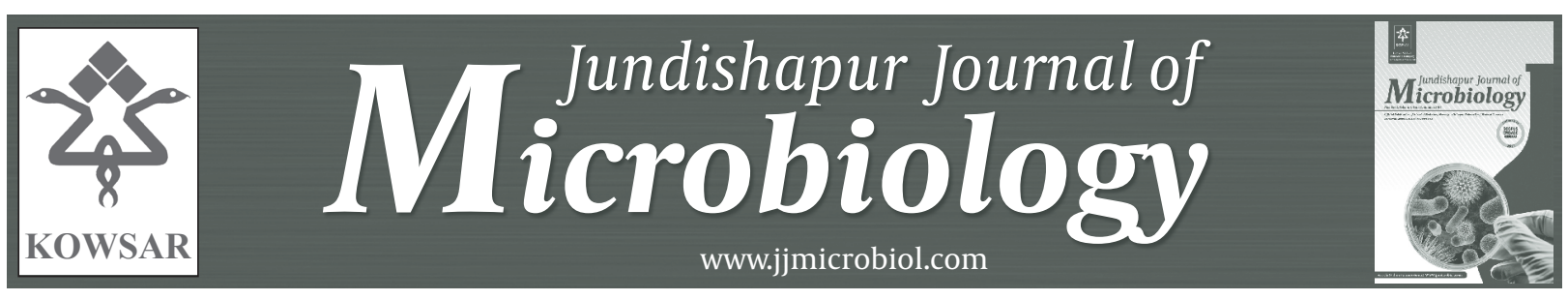

\title{
Combined Application of Microbial Cellulose and Papaver macrostomum Ex- tract on Bedsore Microorganisms
}

\author{
Anita Khanafari ${ }^{1, *}$, Golnaz Yaghoub Nezhad Zangeneh ${ }^{1}$, Fariba Sharifnia ${ }^{2}$ \\ ${ }^{1}$ Microbiology Department, North Tehran Branch, Islamic Azad University, Tehran, IR Iran \\ 2 Biology Department, North Tehran Branch, Islamic Azad University, Tehran, IR Iran \\ *Corresponding author Anita Khanafari, Microbiology Department, North Tehran Branch, Islamic Azad University, Tehran, IR Iran. Tel: +98-2122082141, E- \\ mail: khanafari_a@yahoo.com.
}

\begin{abstract}
A B S T R A C T
Background: Bedsore is one of the major problems in all the societies as patients are confined to bed. Due to antibiotic resistant strains being a significant obstacle for cure, many plants and herbs are being used by researchers as medicinal compounds.

objectives: The investigation of synergistic effect of cellulose biopolymer and Papaver macrostomum extract on bedsores bacterial community.

Materials and Methods: Acetobacter xylinum PTTC 1734 was cultured in Schramm-Hestrin (SH) medium and incubated at $30^{\circ} \mathrm{C}$ for 24-48 hours. $\mathrm{NaOH}$ treatment and absolute ethanol were used to extract cellulose biopolymer and plant antimicrobial substance, respectively. The Biopolymer structure was scanned by a Scanning electron microscope (SEM). Antimicrobial activities, minimum inhibitory concentration (MIC), and minimum bactericidal concentration (MBC) of these extracts were all determined separately. The effective concentration of each extract's alone, combined, and synergistic effects were evaluated. Biopolymer absorption efficiency was assayed as the absorbent bed.

Results: Pesudomonas aeruginosa, Escherichia coli, and Staphylococcus aureus were the dominate bacteria isolated from bedsore samples. Antimicrobial effects of cellulose, P. macrostomum extract, and the combination of both were determined on the isolated bacteria as 1 , 10 , and $15 \mathrm{~mm}$ respectively. $100-1000 \mu \mathrm{l} / \mathrm{mL}$ of flower ethanol extract concentrations of P. macrostomum indicated the maximum effect on mixed bedsore's bacteria rather than leaf and mixed extraction. Concentrations $500-1000 \mu \mathrm{l} / \mathrm{mL}$ decreased the bacterial bedsore's growth and completely inhibited it. 3.5g/L of cellulose biopolymer was obtained from A. xylinum broth culture medium. Scanning electron microscopy analysis confirmed the branched structure of this polymer. Cellulose absorption efficiency was evaluated to be $14.5 \mathrm{ml} / \mathrm{g}$ in this investigation. Because of high-absorbance of bio-cellulose, combined plant extraction with this biopolymer caused a decrease in the growth of bedsore microorganisms with the minimum extract concentration, $100 \mu$ l.

Conclusions: Combination of bio-cellulose and P. macrostomum flower ethanol extract can be used for patients who suffer from bedsore lesions in concentration $0.1 \%$ of MBCs. Furthermore, clinical studies are needed to confirm the efficiency of in vivo application.
\end{abstract}

Keywords: Bedsores; Acetobacter xylinum; Cellulose Biopolymer; Papaver macrostomum; Antimicrobial Effect

Copyright (c) 2013, Ahvaz Jundishapur University of Medical Sciences; Published by Kowsar Corp.

Article type: Research Article; Received: 13 Mar 2012, Revised: 19 Jun 2012, Accepted: 03 Jul 2012; DOI: 10.5812/jjm.4807

Implication for health policy/practice/research/medical education:

The results of this study indicate that combination of ethanol flower extract of $P$. macrostomum and bio-cellulose obtained from $A$. xylinum as bioactive and natural materials could eliminate bedsore microbial infection at low concentration.

-Please cite this paper as:

Khanafari A, Yaghoub Nezhad Zangeneh G, Sharifnia F. Combined Application of Microbial Cellulose and Papaver macrostomum Extract on Bedsore Microorganisms. Jundishapur J Microbiol. 2012;6(3):220-5. DOI: 10.5812/jjm.4807

Copyright @ 2013, Ahvaz Jundishapur University of Medical Sciences; Published by Kowsar Corp.

This is an Open Access article distributed under the terms of the Creative Commons Attribution License (http://creativecommons.org/licenses/by/3.0), which permits unrestricted use, distribution, and reproduction in any medium, provided the original work is properly cited. 


\section{Background}

Bedsores (pressure sores) are kind of skin ulcers usually over bony areas which are caused by prolonged pressure on the skin compressing the small vessels, resulting in restriction of nutrients and oxygen to the tissue, leading to the death and sloughing off of tissue cells, and infections caused by microbial invasion of the damaged skin tissue (1). This kind of ulcer occurs in four stages including reddening area, redness with blistering, breakdown of the uppermost layers of skin or the dermis, and breakdown of the subcutaneous skin layers including deeper tissue and even muscle fascia (2).

These ulcers are common and serious complications in individuals who have spinal cord injury and use a wheelchair, are bedridden and unable to change positions, have a poor nutrition or hygiene, or are diabetics $(1,2)$.

A variety of microorganisms including gram-positive cocci of the normal microflora e.g. Staphylococcus epidermidis and Gram-negative pathogen e.g. Pseudomonas aeruginosa, which are known for causing nosocomial infections, could infect the wounds and may cause the limited options for antibiotic treatment and life threatening consequences (3).

In recent years, application of natural or chemical substances with antibacterial activity e.g. azithromycin and medicinal plants e.g. Mentha piperita L., Foeniculum vulgare L., honey, and propolise were used to relieve various types of dermatitis caused by bacteria and fungi (4). Antiseptics and disinfectants such as plain liquid soap, betadine, and iodine are also used to minimize contamination, infections, and treatment of adults and children $\operatorname{skin}(5,6)$.

A huge variety of biopolymers, such as polysaccharides, polyesters, and polyamides are naturally produced by microorganisms which have antimicrobial effects and can be used as wound dressing. One of these biopolymers is bacterial cellulose which displays unique physical, chemical, and mechanical properties including high crystalline and water holding capacity, large surface area, elasticity, mechanical strength, and biocompatibility which has potential applications in food preparations, drug delivery agents, capsule shells, oil spill cleanup sponge, mineral and oil recovery, leather products, and also in ultra-filters for water purification, audio speaker diaphragm, plywood laminates, and automotive and aircraft bodies (7).

According to Pokalwar et al. one of the best materials to promote wound healing from second and third degree burns is bacterial cellulose (8). This microbial polymer is a proper substitute of natural resources (plants) which could help in the protection of global climate by preventing deforestation $(8,9)$.

Ability to synthesize bacterial cellulose has been exhibited by variety of microorganisms including Sarcina spp.,
Agrobacterium spp., Rhizobium spp., Acetobacter spp., and Gluconacetobacter spp., specially Gluconacetobacter xylinus (4).

\section{Objectives}

The purpose of this current research was the investigation of synergistic effect of cellulose biopolymer extracted from A. xylinum and ethanol P. macrostomum extract on bedsores' bacterial community.

\section{Materials and Methods}

This research was carried out in Microbiology Laboratory, North Tehran Branch, Islamic Azad University, TehranIran, during 2010 to 2011. All data reported in this study are from triplicate measurements.

\subsection{Bacterial Strains and Culture Conditions}

A. xylinum PTTC1734 was originally obtained from Persian Type Culture Collection (PTTC) of Iranian Research Organization for Science and Technology in Tehran-Iran. Bacterium strain was cultured in Schramm and Hestrin (SH) medium (yeast extract 5g; peptone $5 \mathrm{~g}$; glucose $20 \mathrm{~g}$; citric acid 1.15g; disodium phosphate 2.7g; MgSO4 5.7g; distilled water $1000 \mathrm{ml}$, and final $\mathrm{pH}$ adjusted to 6), and incubated at $30^{\circ} \mathrm{C}$ in $200 \mathrm{rpm}$ shaking condition for $24-48$ hours.

20 samples of bedsore lesions in adults (35 to 60 years old) were kindly provided from Hafte Tir Hospital center in Tehran under supervision of qualified lab pathologist by collecting with sterile cotton swabs used for isolation of bacteria, cultured on EMB and blood agar media (Merck, Germany), and incubated at $37^{\circ} \mathrm{C}$ for $48-72$ hours. Classic physiological characteristics such as oxidase test, indole production, coagulase test, MR-VP test, oxidationfermentation test, carbohydrate utilization, etc., were tested according to Bergey's Manual of Determinative Bacteriology (10).

\subsection{Bacterial Inoculum Cultures}

A. xylinum (PTTC1734) inoculum culture was performed in Schramm and Hestrin(SH) broth medium and incubated at $30^{\circ} \mathrm{C}$ for $48-72 \mathrm{~h}$. Bacterial cell density was adjusted to 0.257 at $600 \mathrm{~nm}$ (equal to $3 \times 10^{8} \mathrm{CFU} / \mathrm{ml}$ ) by UV-VIS scanning spectrophotometer, UV-VIS scanning spectrophotometer, UV 2101pc, Shimadzu (11).

\subsection{Isolation, Purification, and Biosynthesis Pro- cess Yield Determination of Bacterial Cellulose}

A. xylinum PTTC1734 inoculum culture 3-5\% was added to Schramm and Hestrin (SH) medium, incubated for 24$48 \mathrm{~h}$ at $30^{\circ} \mathrm{C}$ in $200 \mathrm{rpm}$ shaking condition. According to Bae et al. bacterial cellulose which formed on the top of the medium as a pellicle, was removed and treated with 
$4 \mathrm{~N} \mathrm{NaOH}$ solution at $100^{\circ} \mathrm{C}$ for $30 \mathrm{~min}$ to eliminate the bacterial cells, and then rinsed with $0.5 \mathrm{~N}$ acetic acid and deionized water. The procedure was repeated three times and finally bacterial cellulose was dried in oven at $70^{\circ} \mathrm{C}$ (12).

Dry isolated biopolymer structure was viewed and studied by Scanning electron microscope (SEM) equipped with Energy Dispersive Spectroscopy (EDS) (LEO 440i England) (Roane, 1999).

The yield of the biosynthesis process was calculated in the following way:

$\mathrm{T}=($ amount of glucose consumed $\div$ total amount of glucose) $\times 100$

\subsection{Plant Sample}

P. macrostomum samples were collected at bloom stage from Evin-Darake in North of Tehran in May 2010, identified and authenticated by plant taxonomist according to Iranica flora. Voucher specimens were kept at the Herbarium of Plant Biology Department in North of Tehran Branch, Islamic Azad University, with number 15120.

\subsection{Preparation of the Plant Extract}

Flower and leaves of P. macrostomum samples were separated, dried at $50^{\circ} \mathrm{C}$, and milled by an appropriate blender. Three samples of flower, leaves, and a mix of both were extracted with ethanol solvent $(1: 10)$ at $4^{\circ} \mathrm{C}$ for $48 \mathrm{~h}$. Samples were filtered by a Whatman grade No.1 filter paper, dried at room temperature, and then dried mass weight was determined (13).

\subsection{Antimicrobial Tests}

Antimicrobial activities of plant ethanol extract and cellulose biopolymer on isolated bacterial strains from bedsore lesions were evaluated by Disc diffusion and Serial broth dilution methods to determine minimum inhibitory concentration (MIC) and minimum bactericidal concentration (MBC), respectively as following (14):

\subsubsection{Disc Diffusion Method}

Blank discs were immersed in plant extract (flower, leaves, and mix of both). Dried weight adsorb on each disc was calculated and were placed on Muller Hiton agar medium (Merck, Germany), seeded with isolated bacteria inoculum culture, incubated at $37^{\circ} \mathrm{C}$ for $24 \mathrm{~h}$, and finally inhibition zone around the discs were determined (14).

\subsubsection{Serial Broth Dilution Method}

Serial dilutions of plant (flower, leaves, and mix of both) extract were prepared from 100 to $1000 \mu \mathrm{l} / \mathrm{mL}$ in MullerHinton broth medium (Merck, Germany), then $1 \mathrm{ml}$ of each isolated bacteria inoculum samples was added, and then incubated at $37^{\circ} \mathrm{C}$ for $24 \mathrm{~h}$.
To determine the antimicrobial effect of cellulose biopolymer isolated from A. xylinum PTTC1734, above steps were set up in presence and absence of plant extract with $0.01 \mathrm{~g}$ bio-cellulose.

\section{Results}

The results showed that P. aeruginosa (60\%), E. coli (35\%), and S. aureus (5\%) were dominant bacterias in all 20 bedsore samples.

A. xylinum PTTC1734 could produce bacterial cellulose in the form of film on the surface of medium after incubating at $30^{\circ} \mathrm{C}$ for $24-48 \mathrm{~h}$ in Schramm and Hestrin (SH) medium (Figure 1).

Scanning electron micrograph of bacterial cellulose portrayed the fibril structure with great homogeneity and branched texture (Figure 2).

The yield of cellulose biopolymer was determined to be $3.5 \mathrm{~g} / \mathrm{L}$ with $100 \%$ consumption of glucose in the medium by A. xylinum PTTC1734 (Figure 3).

The most effective antimicrobial inhibition zone and minimum bactericidal concentration (MBC) on mixed bedsore microorganisms were evaluated by ethanol flower extract of $P$. macrostomum with $10 \mathrm{~mm}$ in diameter and $1000 \mu \mathrm{l} / \mathrm{L}$, respectively (Table 1).

Cellulose biopolymer did not show a significant antimicrobial effect (with $1 \mathrm{~mm}$ inhibition zone). But mixture of this biopolymer and ethanol flower extract of $P$. macrostomum could cause inhibition of bedsore microorganisms's growth at lower concentration of flower extraction $(100 \mu \mathrm{L}$ per $0.01 \mathrm{~g}$ cellulose) with $15 \mathrm{~mm}$ inhibition zone.

Cellulose absorption efficiency was evaluated to be 14.5 $\mathrm{ml}$ of plant extract per gram of dried cellulose in this investigation.

\section{Discussion}

The fact that bedsores are very common problems faced by many elderly people who are bedridden, in a coma, or immobile; and because of antibiotic resistance, most of antimicrobial treatments are not useful and many researchers focus on the usage of herbs or plant extractions instead of chemotherapy.

In current research, 60\% P. aeruginosa, 35\% E. coli, and $5 \%$ S. aureus were considered as dominant bacterias that were isolated and confirmed with biochemical tests from 20 medical skin lesion samples.

One of the major problems to cure bedsore lesions is mixed infection. According to Ghaly et al. S. epidermidis was the most predominant pathogen isolated from pressure sores and ulcerations in the primary stage with frequency of 31.4\%; followed by Proteus vulgaris (28.6\%), P. aeruginosa (22.8\%), E. coli (8.6\%), K. pneumonia (5.8\%), and S. aureus (2.8\%). Therefore the percentage of bacterial bedsore infections could be different based on the environment and skin flora of patients (4). 
Figure 1. Production of Bacterial Cellulose
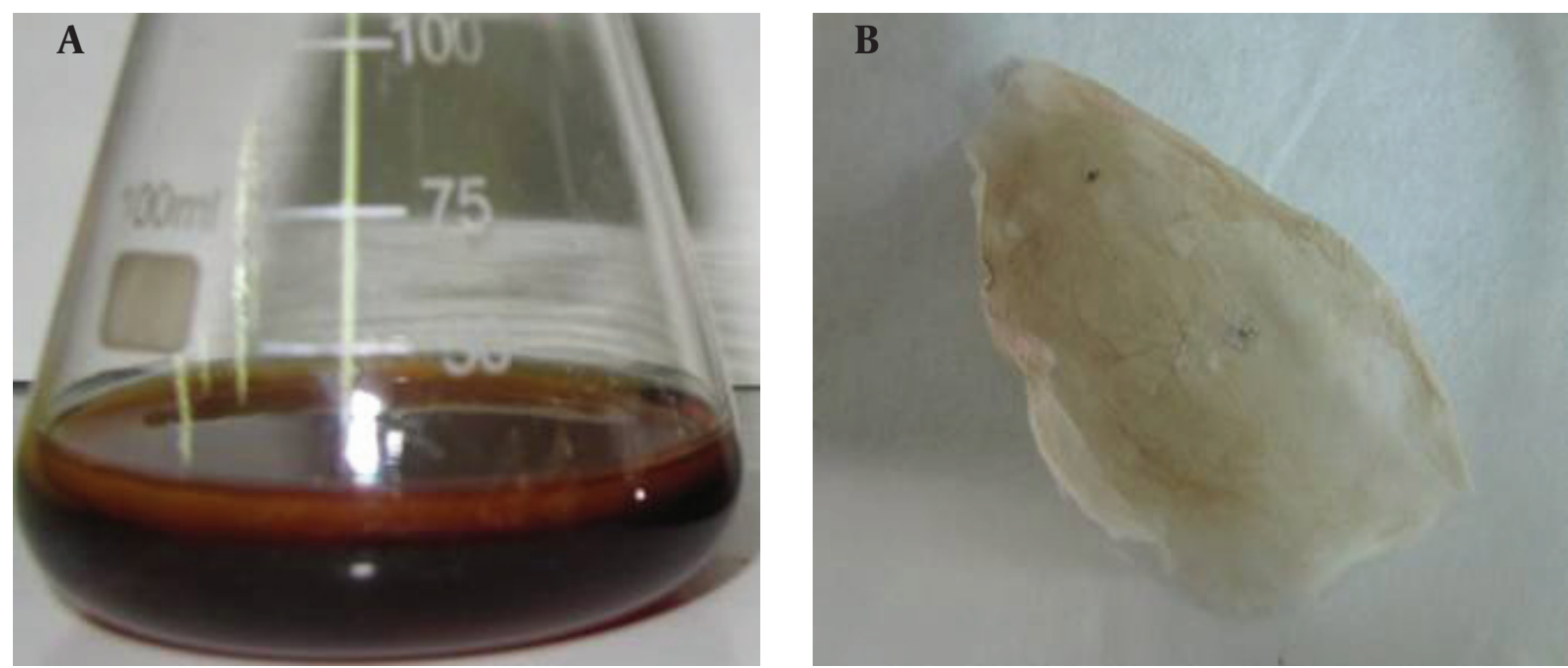

a) Bacterial cellulose pellicle produced on the surface of Schramm and Hestrin ( $\mathrm{SH}$ ) medium after incubating at 30 degrees centigrade for 24-48h, b) bacterial cellulose in the form of film after treating with $4 \mathrm{~N} \mathrm{NaOH}$ solution at 100 degrees centigrade
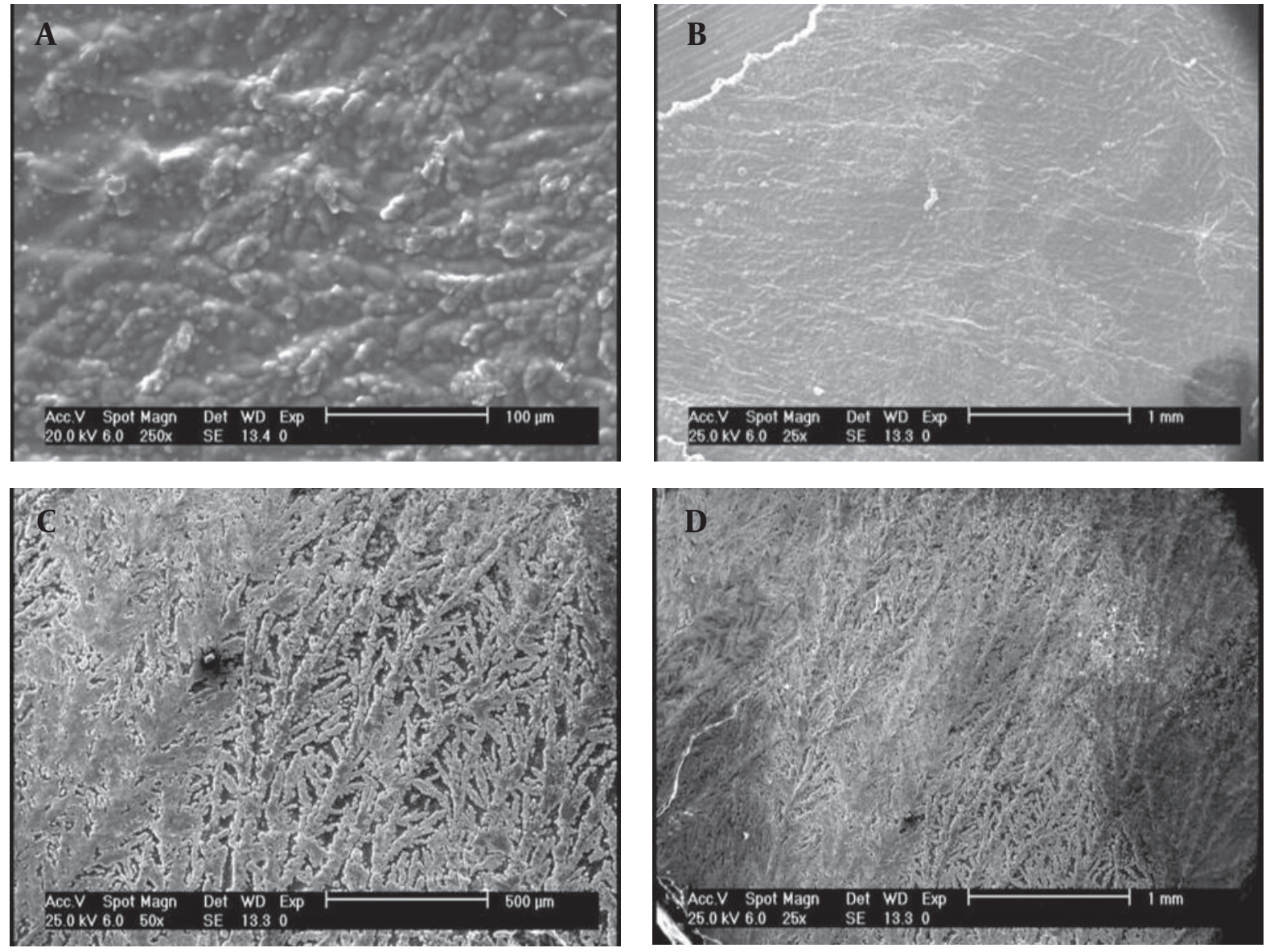

Figure 2. Fibril Structure of Bacterial Cellulose Surface Displayed by Scanning Electron Microscope (SEM) (25kV, 25×) 


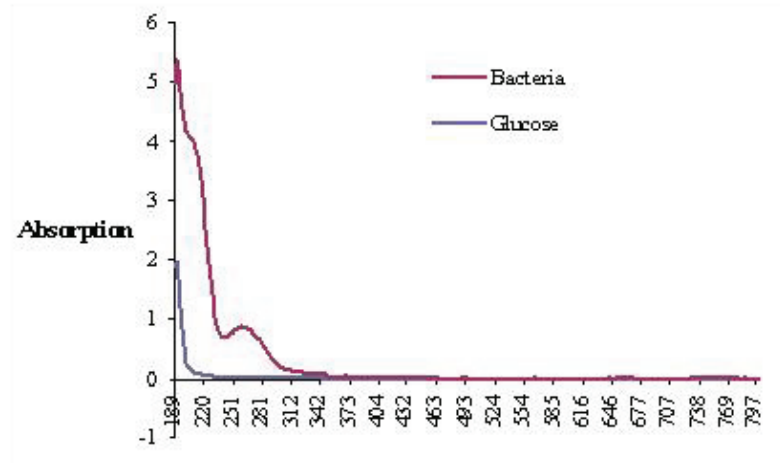

Wave length (nm)

Figure 3. TheEfficiency of Cellulose Production and Glucose Consumption by A. xylinum PTTC1734

Table 1. Antimicrobial Effect of Plant Extraction on Mixed Bedsore Microorganisms

\begin{tabular}{llll}
\hline Antimicrobial Effect & Flower & Leaf & $\begin{array}{l}\text { Mix } \\
\text { (Flower+Leaf) }\end{array}$ \\
\hline $\begin{array}{l}\text { Antimicrobial inhibi- } \\
\text { tion zone, mm }\end{array}$ & 10 & 8 & 9 \\
$\begin{array}{l}\text { Antimicrobial inhibi- } \\
\text { tion zonemixed with } \\
\text { bio-cellulose, mm }\end{array}$ & 15 & 12 & 10 \\
\hline MIC, $\mu \mathrm{L} / \mathbf{m L}$ & 500 & 600 & 750 \\
\hline MBC,, $\mathbf{L} / \mathbf{m L}$ & 1000 & 1000 & 1000 \\
\hline
\end{tabular}

The use of chemicals and natural antimicrobials are common in treatment of bacterial infections (4). In current research, $P$. macrostomum ethanol extract was used for the reduction of bacterial bedsore infections.

In many researches, antimicrobial properties of $P$. macrostomum are shown. Three alkaloids including Cheliantifoline, Mecambrine, Laudanosine, and two flavonoids Luteoline and Tricine of the P. macrostomum species have been shown to possess antimicrobial properties against most gram-positive and gram-negative bacteria. Ünsal et $a l$. showed that diethyl ether and acetone extracts of two samples obtained from the aerial parts of the P. macrostomum Boiss. \& Huet ex Boiss. Papaveraceae of Turkish origin had antimicrobial activity against almost all bacteria that were tested (16).

In addition to microbial effect, different extracts of poppy due to existence of morphine, thebaine, codeine, and oripavine are applied to produce sedative medicines $(3,17)$. The result showed that ethanol flower extract of $P$. macrostomum was more effective than others. It seems that there are more effective antimicrobial compounds in ethanol flower extract of P. macrostomum than the other parts.

Because bedsore is a painful disease, it is better to use antimicrobial substances in a bio-polymeric adsorbent. These materials could help reduce the wound's moisture, and decrease contact between the wound and clothing or bed sheet. So in this study cellulose biopolymer was an adsorbent isolated by boiling in $\mathrm{NaOH} 4 \%$ from A. xylinum PTTC 1734 with $3.5 \mathrm{~g} / \mathrm{L}$ yield. The result showed that this bacterium consumed glucose100\% and transformed it to bio-cellulose.

Medical application of microbial cellulose in the treatment of different types of wounds on a large scale was initiated in the early 1980 s (17). Unique properties of cellulose biopolymer has created a new wound healing system based on microbial cellulose produced by Acetobacter spp. for the usage in the therapy of burns and ulcers, as temporary artificial skin, and for treatment of periodontal diseases.(18).

The result showed that cellulose biopolymer had no significant antimicrobial effect on mixed bacterial infection. But when it was used with plant extraction, antimicrobial effect of extraction was increased from $1000 \mu \mathrm{L} /$ $\mathrm{mL}$ to $100 \mu \mathrm{L} / \mathrm{mL}$. It seems that this substance is a good sorbet and could trap the bacteria and reduce the number of them due to it having a branched fibril structure. So to eliminate the microbes less extract is needed.

In conclusion the results showed that the combined application of ethanol flower extract of $P$. macrostomum and bio-cellulose obtained from A. xylinum PTTC 1734 could eliminate bedsore microbial infection at a low concentration of $100 \mu \mathrm{L}$ and $0.01 \mathrm{~g}$ respectively (0.1\% of MBCs concentration). These natural materials and other bioactive plant extracts can be used for infection treatments rather than antibiotics to decrease antibiotic resistance. Furthermore, clinical studies are needed to confirm the efficiency of in vivo application.

\section{Acknowledgements}

The authors would like to thank Dr. Reza Marandi, University Vice-Chancellor, and assistance of microbiology laboratory for facility research services.

\section{Financial Disclosure}

Authors don't have any Financial Disclosure.

\section{Funding/Support}

This study was performed at Microbiology Department, North Tehran Branch, Islamic Azad University and was supported by the Office of Graduate Studies. The authors are grateful to the Office for its support.

\section{Authors' Contribution}

None declared.

\section{References}

1. Baeke JL. Hospital-acquired pressure ulcers: an epidemic. Plast Reconstr Surg. 2000;106(4):945-6

2. Braden BJ, Maklebust J. Preventing pressure ulcers with the 
Braden scale: an update on this easy-to-use tool that assesses a patient's risk. Am J Nurs. 2005;105(6):70-2

3. Aridogan BC, Baydar H, Kaya S, Demirci M, Ozbasar D, Mumcu E. Antimicrobial activity and chemical composition of some essential oils. Arch Pharm Res. 2002;25(6):860-4

4. Ghaly MF, Shalaby MA, Shash SM, Baraka DM, Aly RA. Control of Bacterial Contamination of Bed Sores by Using Some Natural Extracts. J Appl Sci Res. 2010;6(1):70-80

5. Rodriguez-Solares A, Perez-Gutierrez F, Prosperi J, Milgram E, Martin A. A comparative study of the efficacy, safety and tolerance of azithromycin, dicloxacillin and flucloxacillin in the treatment of children with acute skin and skin-structure infections. J Antimicrob Chemother. 1993;31 Suppl E:103-9

6. Vieira CD, Farias Lde M, Diniz CG, Alvarez-Leite ME, Camargo ER, Carvalho MA. New methods in the evaluation of chemical disinfectants used in health care services. Am J Infect Control. 2005;33(3):162-9

7. Jain SC, Sharma R, Jain R, Sharma RA. Antimicrobial activity of Calotropis procera. Fitoterapia.1996;67(3):275-277

8. Mishra MK, Manwar AV, Pokalwar SU. Production of Cellulose by Gluconacetobacter sp. Rec Res Sci Technol. 2010;2(7)

9. Kalemba D, Kunicka A. Antibacterial and antifungal properties of essential oils. Curr Med Chem. 2003;10(10):813-29
10. Vos P, Garrity G, Jones D, Krieg NR, LudwigW, Rainey FA, et al. Bergey's Manual of Systematic Bacteriology: Volume 3: The Firmicutes. 2009.

11. Abouhamad WN, Bray D, Schuster M, Boesch KC, Silversmith RE, Bourret RB. Computer-aided resolution of an experimental paradox in bacterial chemotaxis. J Bacteriol. 1998;180(15):3757-64

12. Bae S, Sugano Y, Shoda M. Improvement of bacterial cellulose production by addition of agar in a jar fermentor. J Biosci Bioeng. 2004;97(1):33-8

13. Tosun F, z Kzlay, ener B, et al. The Evaluation of Plants from Turkey for in Vitro Antimycobacterial Activity. Pharm Biol (Formerly International Journal of Pharmacognosy). 2005;43(1):58-63

14. Koneman EW, Allen S, Winn W, Schreckenberger Paul C, William J. Diagnostic microbiology. 1992.

15. Cowan MM. Plant products as antimicrobial agents. Clin Microbiol Rev.1999;12(4):564-582

16. Ünsal Ç, Sarıyar G, Akarsu BGürbüz, Çevikbaș A. Antimicrobial Activity and Phytochemical Studies on Turkish Samples of Papaver macrostomum. Pharm Biol. 2007;45(8):626-630

17. Ross P, Mayer R, Benziman M. Cellulose biosynthesis and function in bacteria. Microbiol Rev.1991;55(1):35-58

18. Czaja W, Krystynowicz A, Bielecki S, Brown RM, Jr. Microbial cellulose--the natural power to heal wounds. Biomaterials. 2006;27(2):145-51 